\title{
Determinants of Financial Performance of Insurance Companies of USA and UK during Global Financial Crisis (2007-2016)
}

\author{
Anam Batool*, Abdullah Sahi \\ Lahore School of Accountancy and Finance, University of Lahore, Lahore, Pakistan
}

\begin{abstract}
The economy as well as insurance industry of USA and UK face decline during last decade. The researcher compares two insurance industries, analysis possible determinants of financial performance during global financial crisis, collected 24 insurance companies' Quarterly data from 2007-16 and applied panel data techniques. Explanatory variables based on internal (Size of firm, liquidity, leverage and asset turnover) and external factors (GDP (Gross Domestic Product), CPI (Cost per Impression), interest rate and WTI (West Texas Intermediate)). Dependent variable: ROA (Return on Assets) and ROE (Return on Equity) (profitability indicators). This study concludes; In USA size of firm, liquidity, leverage, asset turnover, GDP and WTI have positive while CPI and interest rate have negative significant impact. In UK size of firm, liquidity, GDP, CPI and WTI have positive but leverage, asset turnover and interest rate has negative significant impact; US insurance is efficient as compare to UK. These findings will be helpful for insurance industries, government, policymakers and investors in taking decision and improving the performance.
\end{abstract}

Keywords: USA insurance companies; UK insurance companies; Internal factors; External factors

\section{INTRODUCTION}

Everyone around the world expose to possibility of any loss through accident fire, or business and any disaster like death. People need protection against these risks. Insurance firms are very important for corporations, businesses and individuals because insurance firms protect them against any financial losses. In financial services industry the insurance sector is very important in almost all developing and developed countries. It also contributing in reduction of transaction costs, economic growth, efficient resource allocation, facilitation of economies of scale in investment, creation of liquidity, and spread of financial losses [1].

Performance refers to the association between strategic effectiveness and operational efficiency of a specific firm. Improve production processes; product, services and market management are major objective of a firm. Financial performance of any firm related to its profitability of that firm. The financial performance of the firm can be measure by some other different ways like gross margin rate, return on asset and return on equity. Financial performance of the firm is very important to attract the attention of researcher, financial experts and management of other corporations. It is such a difficult task to select a successful company, that why they have to concern with the profitability of the firm. According to Doumpos et al. The financial performance of insurance industry is very important to various stakeholders including agents, policyholders, and policy makers [2].

The global financial crisis hurt the economies of both emerging and developed countries, due to these crisis high risk and high losses started in the United States. As a result these crisis spread out to the other countries [3]. In 2009, the economy of major developed countries faces deep recession. Their trade patterns and volume effected very badly. According to the prediction of OECD the overall world trade volumes decreased by 13 percent in 2009 from the level in 2008 [4].

\section{USA insurance industry}

In term of revenue the insurance industry of USA one of the largest insurance industries in the whole world. In 2011 the insurance industry revenue (premium) was exceeded than $\$ 1.2$ trillion. Due to the crisis of 2009 the premium of insurance industry also affected. The USA insurance industry contribution in GDP is close to $40 \%$. More than 2 million people are employed. As we know the USA insurance industry is the largest insurance industry in the whole world. By the capitalization MetLife, Allstate, AIG and prudential financial are the major players of USA insurance industry

${ }^{*}$ Correspondence to: Anam Batool, Lahore School of Accountancy and Finance, University of Lahore, Lahore, Pakistan, Tel: +923204103768; E-mail: anumbatoo1918@gmail.com

Received: December 11, 2018; Accepted: January 21, 2019; Published: January 28, 2019

Citation: Batool A, Sahi A (2019) Determinants of Financial Performance of Insurance Companies of USA and UK during Global Financial Crisis (2007-2016). Int J Account Res 7:194. doi: 10.35248/2472-114X.19.7.194

Copyright: $\odot 2019$ Batool A, et al. This is an open-access article distributed under the terms of the Creative Commons Attribution License, which permits unrestricted use, distribution, and reproduction in any medium, provided the original author and source are credited. 


\section{UK insurance industry}

UK insurance industry plays an important role in leading the global insurance market of the whole world. In tax payment UK insurance industry contributes up to $£ 10$ billion and $£ 1,478$ billion is the total value of asset of insurance industry. More than 310,000 people are employed. In UK insurance industry $£ 5.5$ billion insurance related to exports and its contribution in GDP of UK is 0.4 per cent. $25 \%$ of country net worth's investment linked to the insurance industry. Insurance sector prove to be resilient even during the worst financial crisis.

\section{Comparison of USA and UK industry}

There are two different conglomerate states in the world, which is USA and UK. USA has constitutional and federal republic form of government on the other hand the UK instills the constitutional monarchy-parliament governance. The UK is more of an archipelago. In contrast the USA is more of continent. Similarly UK was very powerful nation in $19^{\text {th }}$ century and in present the USA is more powerful nation in the whole world. These are some reason to choice these two nations USA and UK for comparison in this research.

\section{Problem statement}

In the previous section, numbers of studies have been conducted on the determinants of financial performance of insurance companies of different countries [5]. In some studies, different explanatory variables have been selected and analysis the determinants of financial performance of insurance companies. Berteji and Hammami studied determinants of the performance of the life insurance companies in Tunisia, similarly Boadi et al. analysis the determinants of financial performance in Ghana [6,7]. Malik also investigate the performance of insurance companies of Pakistan [8]. Similarly, there are a lot of studies like Mehari et al. (2013) and Charumathi $[9,10]$. Very few studies focused on internal and external factors that have been affected the profitability of insurance companies. Omondi and Almajali et al. study based on factors that affect the financial performance of listed companies in Kenya. Almajali et al. studies based on both internal and external factors as the key determinants of performance of companies as the factors that affecting the financial performance of listed companies $[11,12]$. In past, many areas are studied by a number of scholars, but still many issues are not solved in the literature. These literature gaps are understandable because every country have different economic, financial and political structure. Similarly, over the time period the insurance industry profitably not remain same, it varies. Very few studied found in the comparison of two insurance industries in different countries.

This study contributes to the literature in many ways.

- First, the researcher investigated the determinants of financial performance of insurance companies of USA and UK during global financial crisis.

- Policy makers of insurance companies to access current policies and also can adjust management mechanisms to achieve profitability.

- Policy makers to reform the consequences of insurance industry performance on the economy of USA and UK.

- Management to hedge any type of risk against insurance industry, and macroeconomic related factors to being improvement in overall performance of the insurance sector.

- Researchers to expand this research area to other countries.

- Shareholders to assess the performance of insurance industry in terms of profitability indicators.

\section{Research objectives}

By exploring the better results, the study included macro and micro factors that were considered as explanatory variables. These variables explained the relationship with the profitability of insurance firms in a good manner.

- Identify the major determinants of financial performance of insurance companies of USA

- Identify the major determinants of financial performance of insurance companies of UK

- To identify the extent to which internal/external factors hinder profitability of insurance companies of USA

- To identify the extent to which internal/external factors hinder profitability of insurance companies of UK

- To investigate the relationships between different factors and profitability of insurance companies of USA

- To investigate the relationships between different factors and profitability of insurance companies of UK

\section{LITERATURE REVIEW}

Liu et al. studied reinsurance and liquidity of insurance companies of UK. They tested the impact of liquidity on reinsurance over the period of 1994 to 2011 [13]. They took general insurer of UK as sample from synthesis non-life. They selected 17 explanatory variables which were influenced liquidity impact on reinsurance. They applied $\mathrm{R}^{2}$ and adjusted $\mathrm{R}^{2}$ method. It was clearly demonstrated that cash constraints show substitutions arguments. It was also found there was strong relationship between liquidity and reinsurance. It was found that if the insurer had high liquidity then they prefer to purchase reinsurance because there was U-shaped relationship existed between reinsurance and liquidity. It was also found there was strong relationship between liquidity and reinsurance. They argued the insurer manger managed both liquidity as well as reinsurance; reinsurance was very expansive so insurer normally avoids purchasing it while risk adverse manger buys it and investing in liquid asset as well. They also suggested company should pay extra attention on less liquid assets whose purchase less reinsurance because it had negative impact on underwriting risk of the firm as well as liquidity risk, as the result insolvency risk of the firm increased. Insolvency risk created serious problem for the firm.

Berteji et al. size and growth had positively affected the performance of the firm but age affected negatively [6]. But Mwangi et al. found size; growth and age of firm were uncorrelated with the performance of the firm [5]. On the other hand, Omondi et al. finding was totally opposite [11]. They demonstrated size of firm had negative impact on the financial performance of firm while age had positive impact.

Kaya studied the effect of firm specific factors on profitability of the non-life insurance companies of turkey [14]. He selected 24 nonlife insurance companies as a sample and collected data from 2006 
to 2013. He took 192 panel data sets. It was found profitability categorize into further two categories, sales profitability ratio and technical profitability ratio. Current ratio, premium growth rate, loss ratio, size of firm and age of firm all of these firm specific factors were very important and also had positive or negative effect on the profitability of the no life insurance firms in turkey. In result, He argued premium growth and size of the firm had positive impact on the profitability of the firm on the other hand current ratio, loss ratio and age of the firm had negative impact on the profitability of the firm. He also argued size of the firm increase the profitability of large non-life insurance firm as compare to small non-life insurance firms that's why the manager of firm gave extra attention on the growth of firm, for this purpose they could adopted the strategies of merging and acquisitions. On the other hand, loss ratios indicate under writing risk. So, the firm also gave attention on the underwriting risk if under writing risk was low it increases profitability of firm. He also suggested current ratio lead low liquidity of non-life insurance firm which was also increase the profitability as compare to high liquidity.

Shiu examined determinants of UK general insurance companies' performance during the period 1986-1999 [15]. The author selected 211 firms and Different number of firm specific and economic variables selected. They applied least square regression model and two panel data model to calculate results. He argued there was a positive relationship between performance of insurance and interest rate, ROE, liquidity, and solvency margin. There was negative relationship between performance and reinsurance dependence and inflation. Risk was also very important factor and has positive or negative impact on the performance of insurance firm. The performance on whole insurance industry was also affected when the firm faced poor underwriting results and low interest earning. If the interest earning was low its mean the investment earning also affected.

Pervan et al. demonstrate positive correlation between market share and profitability of insurance company [16]. Sumaira et al. demonstrated risk had negative impact on the profitability of firm [17]. But on the other hand Ahmadimousaabad et al. found positive relationship between risk and structure of the firm [18].

Chang investigated determinants of demand for reinsurance for US property-liability insurance industry [19]. The author took data from 2006 to 2010. He conducted research on 13 variables and also develop hypothesis. He applied quantile regression analysis on these selected variables. He argued within various quantile reinsurance the sign of liquidity and loss development was vary. The traditional approaches included 2SLS (Statistical Load Summary) and 2SQR (Structured Query Report) was also applied and 2SLS approach provided biased and insufficient explanation regarding the demand of reinsurance. On the other hand, 2SQR approach was very efficient as well as very helpful to provide more meaningful information as compare to 2SLS approach. Regulators, policy maker as well as policy holders pay more attention on bankruptcy problems and financial pressure of insurer.

Ammari et al. tested board structure and firm performance of French firm listed in SBF 120. They Conducted research from 2002-2009 on 40 French companies which were listed in index named SBF 120 and almost 320 observations [20]. They studied the relationship between board structure and their performance and the factor that affected the firms and collected data from annual reports of respective company. They selected 4 financial ratios and 5 other explanatory variables to measure the validity of their study hypothesis. They applied dynamic panel system GMM (Generalized Method of Moments) and developed hypothesis. They suggested there was negative correlation between board size on the firm and financial performance of French firm. There was positive correlation between independence of director on board of the firm and financial performance of the firm. They also argued if there was any conflict occurred between chairmanship and leadership, it influences negatively the performance of the French firm. They argued the relationship among governance and performance may be created fundamental issue regarding corporate governance and board structure affected the performance of the firm calculated by Tobin $Q$, market to book ratio, return on equity and return on capital.

Sumaira et al. studied determinants of profitability of insurance sector in Pakistan. Over the time period from 2006 to 2011 [17]. They tested 31 insurance firms of Pakistan as a sample out of 39, selected 7 variables and applied fixed effected and random effected model on these variables. They suggested fixed model gave accurate result rather than other models. They argued earning volatility, size and leverage were the basic determinants of profitability but liquidity was not. There was negative relationship between profitability and leverage, inflation, risk and age of firm. On the other hand, there was positive relationship between profitability and growth opportunities but the impact of growth on the firm profitability was insignificant because growth did not produced even any single outcome. If the insurance firm in Pakistan had high debt it would affect the profitability of the firm negatively. They also suggested insurance should utilize their resource very efficiently and effectively to generate more output. In case of Pakistan terrorisms had affected the insurance industry very badly and also reduced their profitability.

Boadi et al. analyzed determinants of profitability of insurance firm in Ghana. Over the time period between 2005- 2010 [7]. They selected 16 insurance firm and data collected from their annual reports. They conducted quantitative research on 6 variables, used ordinary least square and panel method to develop the relationship between these variables and also checked their relationship with profitability of insurance firm. They demonstrate there was positive correlation between profitability, leverage, and liquidity. On the other hand, there was negative correlation between profitability and tangibility. They suggested we can also check the relationship between profitability and return on equity ratio as well.

Boadi et al. found leverage, and liquidity had positive correlation between profitability of insurance firm [7]. Charumathi study showed liquidity and profitability had positive correlation while leverage had negative correlation with profitability [10]. But according to Berteji et al. found both liquidity and leverage had no impact on the performance of insurance companies [6]. Mwangi et al. argued leverage had positive impact but liquidity had no impact on insurance company performance [5].

Charumathi investigated on the determinants of profitability of life insurer in India, over the time 2008-2011 [10]. He conducted research on 23 life insurance companies and selected as sample in which 1 was public and other 22 was private insurance companies, 6 explanatory variables had been selected. Linear multiple regression model had been applied on variables, checked their impact on the profitability of firm and developed hypothesis. He suggested liquidity and size of the company had positive impact on the profitability of the firm but on the other hand equity capital, leverage and premium growth had negative impact on the 
profitability, it was also found there was no relationship between profitability and under writing risk. He argued the firm can improve their profitability by increasing foreign direct investment and focus of designing products that had providing protection and long term saving to the economy. By doing this the insurance industry profitability increased.

Malik undertook determinants of insurance companies' profitability in Pakistan. Over the time 2005-2009, sample included 35 listed insurance companies [8]. 6 financial ratios selected as variables, run regression model and developed hypothesis on these selective variables. He collected data from the financial statement of respective insurance company financial publication of SBP (Small Business Program). It was found there was no relationship between age of firm and profitability. Size of firm and volume of capital had positive impact on profitability. On the other hand leverage ratio and loss ratio had negative impact on profitability of a firm.

Elango et al. studied the diversification relationship with firm performance in USA property- liability insurance industry [21]. They selected data over the time period of 1994 to 2002. The performance of firm measure by profitability of that firm. They use two main indicators of profitability ROA (return on asset) and ROE return on equity. They selected 14 other variables and calculated standard deviation. They applied various tests like split sample analysis, market measure analysis. They argued there was non-linear relationship between firm performance and product diversification. On the other hand, they also suggest there was complex relationship existing between firm performance return and diversification profile of insurer if we focused on geographic diversification and product integration. Geographic diversification affected the performance of firm and diversifications of product. The firm performance would be excellent if there was the low level of both geographic and product diversification.

\section{METHODOLOGY}

\section{Sample and test}

The population of this study is all insurance companies of USA and UK. In this research total 24 insurance companies are selected, 12 insurance companies of USA and other 12 insurance companies from UK. This selection based on availability of requires data. The lists of selected insurance companies have been provided in Appendix A. The data about these insurance companies are collected quarterly for the period from 2007 to 2016 and applied penal data techniques (fixed effect model and random effect model. This study is focusing on insurance industry and macroeconomicrelated variables. In this study financial performance of insurance companies has been determine during global financial crisis 24 insurance companies of both US and UK has been selected. In which 12 US insurance companies and on the other hand 12 UK insurance companies and some other economic variables include GDP, CPI, and interest rate and WTI oil.

\section{Model of study}

Panel root test: Panel root test is necessary to applying unit root tests check the stationary of data. If the data is not stationary at level then the research check the stationary of data at $1^{\text {st }}$ or $2^{\text {nd }}$ difference as well. In this study the author use following test to check the stationary of data.

- Levin, Lin, \& Chu t
- Im, pesaran and Shin W-stat

- ADF- Fisher-Chi square

- PP-Fisher Chi-square

$R O A_{i t}=\alpha+\beta_{1} S F_{i t}+\beta_{2} L I Q_{i t}+\beta_{3} L E V_{i t}+\beta_{4} A S T_{i t}+$

$\beta_{5} G D P_{i t}+\beta_{6} C P I_{i t}+\beta_{7} I N T_{i t}+\beta_{8} W T I_{i t}+\varepsilon_{i t}$

$R O E_{i t}=\alpha+\beta_{1} S F_{i t}+\beta_{2} L I Q_{i t}+\beta_{3} L E V_{i t}+\beta_{4} A S T_{i t}+$

$\beta_{5} G D P_{i t}+\beta_{6} C P I_{i t}+\beta_{7} I N T_{i t}+\beta_{8} W T I_{i t}+\varepsilon_{i t}$

$\mathrm{ROA}_{\mathrm{it}}$ : Return on asset of insurance industry for time $\mathrm{t}$,

$\mathrm{ROE}_{\mathrm{it}}$ : Return on equity of insurance industry for time $t$,

$\mathrm{SF}_{\mathrm{it}}$ : Size of firm for time $t$,

$\mathrm{LIQ}_{\mathrm{it}}$ : Liquidity ratio for time t,

$\mathrm{LEV}_{\mathrm{it}}$ : Leverage ratio for time $t$,

$\mathrm{GDP}_{\mathrm{it}}$ : Gross domestic product for time $\mathrm{t}$,

$\mathrm{CPI}_{\mathrm{it}}$ : Consumer price index for time $t$,

$\mathrm{INT}_{\mathrm{it}}$ : Interest rate LIBOR for time t,

$\mathrm{WTI}_{\mathrm{it}}$ : West taxes intermediate oil price for time $\mathrm{t}$.

Fixed effect model: In fixed effect model the individual attribute do not change over the time and these may be correlated with dependent variables or not. The fixed effect model treated the constant as a group and also allows taking different variables for each of constant the group. This model is also called LSDV estimator. The LSDV stands for least square dummy variables. To check which test the researcher should apply in their study the WuHaussman test has been applied.

Random effect model: The alternative method of fixed effect model is random effects model. The difference between the random effects and the fixed effects model is that the latter handles the constants as random parameters for each section but not as fixed. The random effect is more effective as compare to fixed effect model. Because random effect model has few parameter as compare to fixed effect to estimate. The random model also allows to add up more explanatory variables and gives them equal value.

$$
\begin{aligned}
& Y_{i t}=\alpha_{i}+\beta_{1} X_{1 i t}+\beta_{2} X_{2 i t}+\beta_{3} X_{3 i t}+\beta_{4} X_{4 i t}+ \\
& \beta_{5} X_{5 i t}+\beta_{6} X_{6 i t}+\beta_{7} X_{7 i t}+\beta_{8} X_{8 i t}+\varepsilon_{i t} \\
& R O A_{i t}=\alpha+\beta_{1} S F_{i t}+\beta_{2} L I Q_{i t}+\beta_{3} L E V_{i t}+\beta_{4} A S T_{i t}+ \\
& \beta_{5} G D P_{i t}+\beta_{6} C P I_{i t}+\beta_{7} I N T_{i t}+\beta_{8} W T I_{i t}+\varepsilon_{i t} \\
& R O E_{i t}=\alpha+\beta_{1} S F_{i t}+\beta_{2} L I Q_{i t}+\beta_{3} L E V_{i t}+\beta_{4} A S T_{i t}+ \\
& \beta_{5} G D P_{i t}+\beta_{6} C P I_{i t}+\beta_{7} I N T_{i t}+\beta_{8} W T I_{i t}+\varepsilon_{i t}
\end{aligned}
$$

Hausman test: The researchers used hausman test to check which model is more appropriate in their studies. There is no correlation existing among dependent and independent variables both model fixed and random are consistent but fixed model are inefficient. Similarly if there are correlation among dependent and independent variables, in this case the random effect model is inconsistent and fixed effect model is consistent.

The hausman test is basically the difference between random and fixed effect.

$\beta_{R E}-\beta_{F E}$ 


\section{Schematic diagram}

This framework shows the internal and external factors that have positive or negative impact on the profitability of any firm. There are two indicators of profitability that is return on asset and return on equity. These indicators can be affected by many factors and also affects the overall performance of any company around the world. In the research the researcher categorize the factors in internal and external factors. The internal factor includes size of firm, liquidity, leverage and asset turnover. The external factors are GDP, CPI, interest rate and WTI oil (Figure 1).

\section{Hypothesis}

The alternative hypotheses are following

$\mathrm{H}_{1}$ : There is a significant impact of internal factors (size of firm, liquidity, leverage and asset turnover) and factors (GDP, CPI, interest rate and WTI oil) on profitability (ROA) of insurance companies of USA.

$\mathrm{H}_{2}$ : There is a significant impact of internal factors (size of firm, liquidity, leverage and asset turnover) and factors (GDP, CPI, interest rate and WTI oil) on profitability (ROE) of insurance companies of USA.

$\mathrm{H}_{3}$ : There is a significant impact of internal factors (size of firm, liquidity, leverage and asset turnover) and factors (GDP, CPI, interest rate and WTI oil) on profitability (ROA) of insurance companies of UK.
$\mathrm{H}_{4}$ : There is a significant impact of internal factors (size of firm, liquidity, leverage and asset turnover) and factors (GDP, CPI, interest rate and WTI oil) on profitability (ROE) of insurance companies of UK.

Decision Criteria=Reject $\mathrm{H}_{\circ}$, if $\mathrm{p}$ value is less than $\alpha$. Or "Accept" $\mathrm{H}_{\mathrm{o}}$, if $\mathrm{p}$ value is greater than $\alpha . A=5 \%$

\section{EMPIRICAL ANALYSIS}

\section{Correlation matrix}

The correlation matrix is basically a table that shows the correlation coefficient among variables individually. The diagonal values of table id always 1 because each variable is perfectly correlated with itself. Correlation matrix tells us weather the variables are correlated with each other or not. If there are any relationships exist among variables. The correlation matrix also tells which type of relationship existing, negative or positive (Table 1).

Correlation matrix shows relationship among variables individually. As the below mentioned Table 2 show worth of relationship which are existing among variables. In US Insurance industry ROA and ROE show positive and strong relationship that is $86 \%$. Similarly, liquidity and size of firm are also positively correlated with each other that are $64 \%$. But on the other hand asset turnover and size of firm negative but very strongly correlated with each other. The worth of relationship is $91 \%$. ROA and ROE Relationship with size of firm is negative and weak which is only $16 \%$, but on the

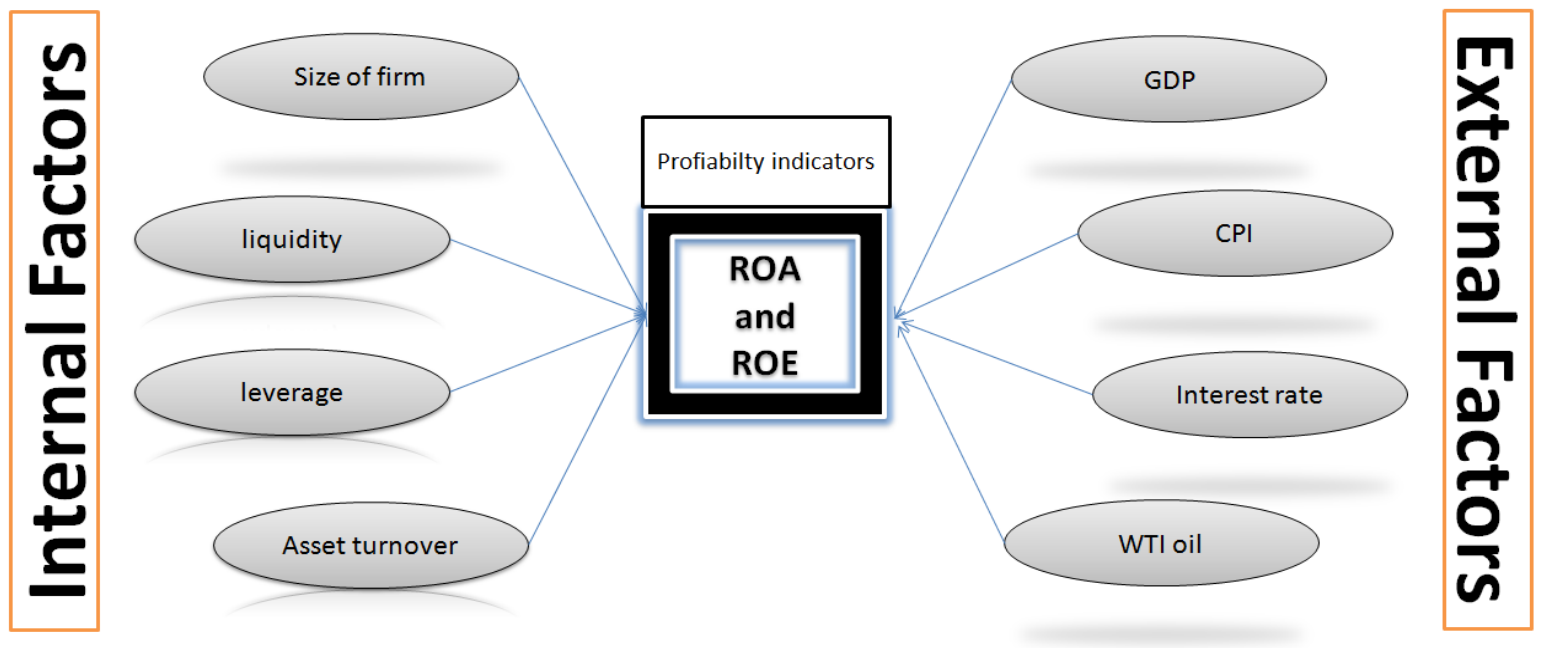

Figure 1: Schematic Diagram of internal and external factors.

Table 1: Brief description of variables.

\begin{tabular}{ll}
\hline Variables & Brief description \\
\hline ROA & Return on assets measures by divided net income to total assets. \\
\hline ROE & Return on equity measures by divided net income to total shareholder equity. \\
\hline SF & Size of firm is measure by the taking log of firm total asset. \\
\hline LIQ & Liquidity is the ratio of current assets and current liabilities \\
\hline LEV & Leverage is measures by divided total liabilities to total equity. \\
\hline AST & Asset turnover shows value of revenue or sales of the company generated relative value of assets. \\
\hline GDP & GDP stands for gross domestic product which shows growth of economy of a country \\
\hline CPI & CPI refers to rate of change in the price of any commodities. \\
\hline INT & Interest rate represent the percentage of amount have been charged to provide services. \\
\hline WTI & WTI stands for west taxes intermediate. It is grade of crude oil and used as benchmark in oil pricing. \\
\hline
\end{tabular}

Notes: Brief description of all dependent and independent variables like ROA, ROE, SF, LIQ, LEV, AST, GDP, CPI, INT, WTI. 
Table 2: Correlation matrix of USA and UK.

\begin{tabular}{|c|c|c|c|c|c|c|c|c|c|c|c|}
\hline \multirow{11}{*}{ USA } & & ROA & ROE & SF & LIQ & LEV & AST & GDP & CPI & INT & WTI \\
\hline & $\mathrm{ROA}$ & 1 & & & & & & & & & \\
\hline & $\mathrm{ROE}$ & 0.858 & 1 & & & & & & & & \\
\hline & SF & -0.16 & -0.041 & 1 & & & & & & & \\
\hline & LIQ & 0.182 & 0.262 & 0.641 & 1 & & & & & & \\
\hline & LEV & 0.101 & 0.118 & -0.01 & -0.081 & 1 & & & & & \\
\hline & AST & 0.399 & 0.331 & -0.91 & -0.404 & -0.01 & 1 & & & & \\
\hline & GDP & 0.378 & 0.221 & -0.89 & -0.363 & -0.01 & 0.943 & 1 & & & \\
\hline & CPI & 0.299 & 0.127 & -0.92 & -0.542 & 0.043 & 0.884 & 0.954 & 1 & & \\
\hline & INT & 0.008 & 0.061 & 0.753 & 0.831 & -0.08 & -0.53 & -0.51 & -0.69 & 1 & \\
\hline & WTI & 0.061 & -0.031 & 0.422 & 0.097 & 0.157 & -0.46 & -0.36 & -0.17 & 0.01 & 1 \\
\hline \multirow{11}{*}{ UK } & & ROA & ROE & SF & LIQ & LEV & AST & GDP & CPI & INT & WTI \\
\hline & $\mathrm{ROA}$ & 1 & & & & & & & & & \\
\hline & $\mathrm{ROE}$ & 0.697 & 1 & & & & & & & & \\
\hline & SF & 0.013 & -0.019 & 1 & & & & & & & \\
\hline & LIQ & -0.04 & 0.111 & 0.051 & 1 & & & & & & \\
\hline & LEV & -0.38 & -0.532 & 0.104 & 0.392 & 1 & & & & & \\
\hline & AST & -0.21 & -0.251 & 0.033 & 0.279 & 0.444 & 1 & & & & \\
\hline & GDP & 0.27 & 0.279 & -0.01 & 0.119 & -0.07 & 0.156 & 1 & & & \\
\hline & CPI & 0.032 & 0.018 & -0.11 & -0.363 & -0.28 & -0.18 & -0.19 & 1 & & \\
\hline & INT & -0.05 & 0.046 & 0.041 & 0.042 & 0.129 & 0.066 & -0.08 & -0.14 & 1 & \\
\hline & WTI & 0.062 & 0.171 & -0.17 & 0.076 & -0.32 & 0.233 & 0.238 & -0.23 & -0.09 & 1 \\
\hline
\end{tabular}

Notes: Shows the correlation among variables individually.

other hand ROA and ROE have positive with liquidity, leverage and asset turnover. GDP and CPI are also positively correlated with each other that are $95 \%$. But on the other hand asset CPI and interest rate negative but very strongly correlated with each other. The worth of relationship is $70 \%$. Similarly, GDP are also negatively correlated with interest rate.

In UK insurance industry ROA and ROE show positive and strong relationship that is $70 \%$. Similarly, debts to equity and asset turnover are also positively correlated with each other that are $44 \%$. But on the other hand ROE and leverage negative but very strongly correlated with each other. The worth of relationship is $53 \%$. Similarly GDP and CPI are negatively correlated with each other that are only $18 \%$.

\section{Descriptive analysis}

It is provides the brief description and summarize the whole data set. Which can be represents the entire data. It classified into two categories, measures of variability and measures of central tendency of data. The measure of variability means minimum and maximum variables, standard deviation, variance, the, and the kurtosis and Skewness. The measure of central tendency consists on mean median and mode. This analysis also helps in to determine the normality of distributions.

The descriptive analyses are conducted on all variables and the results are loaded in Table 3 . In US insurance industry profitability indicators return on asset and return on equity have positive mean values ranging from 0.39 to 1.499 showing the average profitability level of the USA insurance sector. On the other hand, standard deviation measures the dispersion of the ROA and ROE figures. The higher standard deviation value of $\mathrm{ROE}(6.1783$ ) shows more dispersed or differentiated equity returns of all USA insurance industry. In contrast, the lower standard deviation of ROA (0.5971) demonstrated less dispersed return on assets. In UK insurance industry return on asset and return on equity have positive mean values ranging from 0.2000 to 2.4376 showing the average profitability level of the UK insurance sector. On the other hand, standard deviation measures the dispersion of the ROA and ROE figures. The higher standard deviation value of ROE (9.3782) shows more dispersed or differentiated equity returns of all UK insurance industry. In contrast, the lower standard deviation of ROA (0.5204) demonstrated less dispersed return on assets. Similarly, the minimum, maximum, mean, and standard deviations of internal and external factors are computed and showed in Table 4.

\section{Random effect model overall finding}

The researcher applied pooled OLS (Ordinary least squares) model then fixed and random effect model and at the end the researcher applied hausman test on data. After applying the hausman test the probability value is greater than $5 \%$. It means we cannot reject alternative hypothesis and accept the null hypothesis that is random effect model is appropriate for our research. The overall findings of accepted random effect model are showed in Table 4.

In case if USA correlation coefficient $r$ which is equivalent to $41 \%$ and $40 \%$ for internal and external factors impact on ROA and on the other and these values are $53 \%$ and $29 \%$ for external factors impact on ROE. These values represents the variation in return on asset and return on equity are explained internal factors: size of firm, liquidity, debt to equity ratio and asset turnover and external factors: GDP, CPI, and interest rate and WTI oil.

As above mentioned in Table 4 all internal factors like size of firm, debt to equity and asset turnover show significant relationship with profitability expect liquidity. It indicates that size of firm debt 
Table 3: Descriptive analysis of USA and UK.

\begin{tabular}{|c|c|c|c|c|c|c|c|c|c|c|c|}
\hline \multirow{6}{*}{ USA } & & ROA & ROE & $\mathrm{SF}$ & LIQ & LEV & AST & GDP & CPI & INT & WTI \\
\hline & Mean & 0.30 & 1.92 & 5.10 & 0.43 & 1394 & 0.07 & 6.61 & 2.49 & 3.25 & 1.87 \\
\hline & Med & 0.37 & 2.46 & 5.10 & 0.23 & 5.73 & 0.06 & 6.59 & 2.49 & 0.90 & 1.91 \\
\hline & Maxi & 0.88 & 6.51 & 5.21 & 1.98 & 55556 & 0.09 & 6.67 & 2.52 & 16.3 & 2.1 \\
\hline & Mini & -1.72 & -8.93 & 5.02 & 0.16 & 3.82 & 0.05 & 6.55 & 2.45 & 0.34 & 1.52 \\
\hline & Std.D & 0.48 & 2.79 & 0.053 & 0.51 & 8.6 & 0.01 & 0.04 & 0.02 & 4.85 & 0.14 \\
\hline \multirow{5}{*}{ UK } & Mean & 0.08 & 0.77 & 5.54 & 0.17 & 14.47 & 0.03 & 5.83 & 2.49 & 8.86 & 1.87 \\
\hline & Med & 0.09 & 1.22 & 5.66 & 0.14 & 14.20 & 0.02 & 5.83 & 2.56 & 1.2 & 1.91 \\
\hline & Maxi & 0.79 & 3.43 & 5.89 & 0.56 & 21.45 & 0.27 & 5.91 & 2.54 & 127 & 2.09 \\
\hline & Mini & -0.37 & -7.73 & 0.57 & 0.05 & 11.3 & 0.02 & 5.76 & 2.32 & 0.92 & 1.52 \\
\hline & Std.D & 0.16 & 1.91 & 0.79 & 0.11 & 2.19 & 0.04 & 0.04 & 0.04 & 21.8 & 0.14 \\
\hline
\end{tabular}

Notes: ROA: Return on Asset; ROE: Return on Equity; SF: Size of Firm, by taking the log of total asset; LIQ: Liquidity; LEV: Leverage, measure by leverage ratio; AST: Asset Turnover; GDP: Gross Domestic Products; CPI: Consumer Price Index; INT: Interest Rate; WTI: West Intermediate oil rice; these values show mean, median, SD, min, max. All variables measure during the sample period of 2007-2016 of both countries US and UK.

Table 4: Overall Dependent variables relationship with profitability of USA and UK.

UNITED STATE AMERICA

\begin{tabular}{|c|c|c|c|c|c|c|c|}
\hline \multicolumn{4}{|c|}{ RETURN ON ASSET } & \multicolumn{4}{|c|}{ RETURN ON EQUITY } \\
\hline Variables & Coeff & t-value & $\mathrm{R}^{2}$ & Variables & Coeff & $t$-value & $\mathrm{R}^{2}$ \\
\hline SF & $9.837^{*}(1.145)$ & 8.594 & \multirow[t]{4}{*}{$41 \%$} & SF & $85.103^{*}(5.881)$ & 14.47 & \multirow[t]{4}{*}{$53 \%$} \\
\hline LIQ & $0.065(0.055)$ & 1.173 & & LIQ & $-0.265(0.282)$ & -0.94 & \\
\hline LEV & $0.0001 *(0.0001)$ & 3.433 & & LEV & $0.001 *(0.0002)$ & 4.261 & \\
\hline AST & $62.43^{*}(4.669)$ & 13.372 & & AST & $456.98^{*}(23.985)$ & 19.053 & \\
\hline GDP & $44.76^{*}(3.667)$ & 12.21 & \multirow[t]{4}{*}{$40 \%$} & GDP & $281.63^{*}(22.991)$ & 12.25 & \multirow[t]{4}{*}{$29 \%$} \\
\hline CPI & $-76.43^{*}(7.567)$ & -10.1 & & CPI & $-529.58^{*}(47.441)$ & -11.16 & \\
\hline INT & $-0.049 *(0.009)$ & -5.29 & & INT & $-0.425^{*}(0.058)$ & -7.328 & \\
\hline WTI & $2.646^{*}(0.212)$ & 12.501 & & WTI & $13.541^{*}(1.327)$ & 10.21 & \\
\hline \multicolumn{8}{|c|}{ UNITED KINGDOM } \\
\hline Variables & Coeff & $\mathrm{t}$-value & $\mathrm{R}^{2}$ & Variables & Coeff & $\mathrm{t}$-value & $\mathrm{R}^{2}$ \\
\hline SF & $0.009(0.009)$ & 1.189 & \multirow[t]{4}{*}{$42 \%$} & SF & $0.076(0.086)$ & 0.886 & \multirow[t]{4}{*}{$41 \%$} \\
\hline LIQ & $0.187^{*}(0.065)$ & 2.887 & & LIQ & $6.561^{*}(0.666)$ & 9.851 & \\
\hline LEV & $-0.029 *(0.004)$ & -8.26 & & LEV & $-0.569 *(0.036)$ & -15.55 & \\
\hline AST & $-0.229^{* *}(0.1881)$ & -1.216 & & AST & $-3.37^{* *}(1.939)$ & -1.74 & \\
\hline GDP & $1.141^{*}(0.1883)$ & 6.059 & \multirow[t]{4}{*}{$8 \%$} & GDP & $13.56^{*}(2.274)$ & 5.982 & \multirow[t]{4}{*}{$10 \%$} \\
\hline CPI & $0.317^{* *}(0.174)$ & 1.821 & & $\mathrm{CPI}$ & $5.168^{* *}(2.103)$ & 2.458 & \\
\hline INT & $-0.001(0.0003)$ & -0.266 & & INT & $0.008^{* *}(0.004)$ & 2.134 & \\
\hline WTI & $0.015(0.052)$ & 0.299 & & WTI & $1.887^{*}(0.622)$ & 3.033 & \\
\hline
\end{tabular}

Notes: GMM, Gernalized Method of Movement: ROE: Return on Equity computed by divided net income by total shareholder equity: SF: Size of Firm, by taking the log of total asset: LIQ: Liquidity is the ratio of current asset and current liabilities: LEV: Leverage, measure by leverage ratio: AST, Asset Turnover is ratio of net sales and total equity: GDP: total Gross Domestic Products: CPI: Consumer Price Index: INT: Interest rate is interbank offered rate: WTI, West Intermediate oil price standard. The standard error values showed in brace blow the each coefficient value. * ${ }^{* *}$ are showed the significance level at $1 \%$ and $5 \%$.

to equity and asset turnover have positive significant relationship with the dependent variables return on asset and return on equity of insurance companies of United State. But on the other hand liquidity has no significant relationship with return on asset of insurance companies of United State. Similarly the external variables like GDP, CPI, interest rate and WTI oil show significant relationship with profitability. It indicates that GDP and WTI oil have positive significant relationship with the dependent variables return on asset and return on equity of insurance companies of United State. But on the other hand CPI and interest rate have negative relationship with return on asset of insurance companies of United State [22].

In case if $\mathrm{UK}$ correlation coefficient $\mathrm{r}$ which is equivalent to $42 \%$ and $8 \%$ for internal and external factors impact on ROA and on the other and these values are $41 \%$ and $10 \%$ for external factors impact on ROE. These values represents the variation in return on asset and return on equity are explained internal factors: size of firm, liquidity, debt to equity ratio and asset turnover and external factors: GDP, CPI, and interest rate and WTI oil.

As above showed the internal variables like debt to equity and liquidity show significant results but on the other hand size of firm and asset turnover are insignificant. It indicates that liquidity has positive significant relationship with the dependent variables profitability of insurance companies on United Kingdom. But on the other hand debt to equity and asset turnover has negative relationship with return on asset and return on equity of insurance 
companies on United Kingdom. Size of firm has no significant relationship with return on asset of insurance companies on United Kingdom.

As above mentioned only GDP and CPI showed significant result and other variables including CPI, interest rate and WTI oil show insignificant. It indicates that GDP and CPI have positive significant relationship with return on asset of insurance companies on United Kingdom but on the other hand, interest rate shows negative and WTI oil shows positive and insignificant relationship in this research. It also indicates that GDP, CPI, interest rate and WTI oil have positive significant relationship with dependent variable return on equity of insurance companies on United Kingdom.

\section{Finding}

- In USA there are $41 \%$ correlation exist among the internal factors profitability indicator ROA, in contract in UK there are $42 \%$ correlation exist among the internal factors profitability indicator ROA.

- In USA there are $53 \%$ correlation exist among the internal factors profitability indicator ROE, in contract in UK there are $41 \%$ correlation exist among the internal factors profitability indicator ROE.

- In USA there are $40 \%$ correlation exist among the external factors profitability indicator ROA, on the other hand in UK there are $8 \%$ correlation exist among the external factors profitability indicator ROA.

- In USA there are 29\% correlations exist among the external factors profitability indicator ROE, on the other hand in UK there are $10 \%$ correlations exist among the external factors profitability indicator ROE.

- In USA, the internal factors including size of firm, leverage and asset turnover have positive relationship with the profitability of insurance firms but on the other hand the internal factor liquidity shows positive relationship and leverage shows negative relationship with the profitability of insurance companies.

- In USA external factors like GDP and WTI oil have positive correlated and CPI and interest rate are negative correlated with the profitability. In contrast In UK GPD has positive relationship but other factors are insignificant to explain the correlation with the profitability.

\section{CONCLUSION}

USA insurance industry show the internal factors including size of firm, leverage and asset turnover are positively correlated with the profitability indicators that are ROA and ROE. In contrast the internal factor liquidity shows insignificant relationship with the profitability indicators that are ROA and ROE. It means the finding indicates that the insurance companies should increase their size, leverage and asset turnover to enhance their financial performance of USA based insurance companies. On the other hand, the external factors including GDP and WTI oil are positively correlated with the profitability indicators that are ROA and ROE. In contrast the external factors including CPI and interest rate show negative relationship with the profitability indicators that are ROA and ROE. On the based on these finding it can be concluded the high GDP and WTI oil and low CPI and interest rate can gain competitive advantage and safety and then insurance industry achieve highest profitability in United States.

UK insurance industry shows the internal factor liquidity is positively correlated with the profitability indicators that are ROA and ROE. In contrast the internal factor leverage shows negative relationship with profitability indicators that are ROA and ROE. The internal factors including size of firm and asset turnover proved insignificant relationship with the profitability indicators that are ROA and ROE. It means the finding indicates that the insurance companies should increase firm liquidity and decrease leverage ratio to enhance their financial performance of UK based insurance companies. In contrast the external factor including GDP is positively correlated with the profitability indicators that are ROA and ROE. The external factors including CPI, interest rate and WTI oil also positively correlated with the profitability but only one indicator that is ROE. And in the case of other profitability indicate ROA these variables are insignificant. On the based on these finding it can be concluded the high GDP and WTI oil, CPI and interest rate can gain competitive advantage and safety and then insurance industry achieve highest profitability in United Kingdom.

The above points show the USA insurance industry are more effective as compare to UK insurance industry. Because the correlation among firm profitability and internal and external factors are stronger as compare to profitability of UK firms.

For future study the research recommended that, this research and its finding are applied only on insurance industry rather than others. The internal and external factors are limited. For future study the number of variables can be increases. Similarly few numbers of companies are selected in this study due to availability of data. So the future researchers conducted research on large number of insurance companies.

\section{REFERENCES}

1. Das U, Davies N, Podpiera R. Insurance and issues in financial soundness (IMF Working Paper No. 03/138). Washington, DC: The World Bank. 2003.

2. Doumpos M, Gaganis C, Pasiouras F. Estimating and explaining the financial performance of property and casualty insurers: A two stage analysis. The Business and Economics Research Journal. 2012;5:155. 170.

3. Khasawneh MK. Impact of the global financial crisis on gross domestic product growth determinants in selected emerging countries for the period of 2008-2013. International Journal of Economics, Commerce and Management. 2015;3.

4. McKibbin WJ, Stoeckel A. The global financial crisis: causes and consequence. Working Paper in International Economics, 2009;2.

5. Mwangi M, Iraya C. Determinants of financial performance of general insurance underwriters in Kenya. International Journal of Business and Social Science. 2014;5:210-215.

6. Berteji A, Hammami S. The determinants of the performance of the life insurance companies in Tunisia. International Journal of Economics, Commerce and Management. 2016;4:334-343.

7. Boadi EK, Antwi S, Lartey VC. Determinants of profitability of insurance companies in Ghana. International Journal of Business and Social Research. 2013;3:43-50.

8. Malik H. Determinants of insurance companies profitability: An analysis of insurance sector of Pakistan. Academic Research International. 2011;1:315. 
9. Mehri D, Aemiro T. Firm specific factors that determine insurance companies performance in Ethiopia. European Scientific Journal. 2013;9:245-255.

10. Charumathi B. On the determinants of profitability of Indian life insurers: An empirical study. In Proceedings of the world congress on Engineering. 2012;1:4-6.

11. Omondi MM, Muturi DW. Factors affecting the Financial Performance of Listed Companies at the Nairobi Securities Exchange in Kenya. Research Journal of Finance and Accounting. 2013;4:99-104.

12. Almajali AY, Alamro SA, Alsoub YZ (2012) Factors affecting the Financial Performance of Jordanian Insurance Companies Listed at Amman Stock Exchange. Journal of Management Research 4:266-289.

13. Liu HH, Shiu YM, Liu TC. Reinsurance and Liquidity: Evidence from the United Kingdom General Insurance Industry. The International Association for the Study of Insurance Economics. 2016;41:307-324.

14. Kaya EO. The effect of firm specific factors on the profitability of non -life insurance in Turkey. Int J Financial Stud. 2015;3:510-529.

15. Shiu Y. Determinants of United Kingdom general insurance company performance. British Actuarial Journal. 2004;10:1079-1110.

16. Pervan M, Pelivan I, Americ J. Profit persistence and determinants of bank profitability in Croatia. Economic Research. 2015;28:284-298.
17. Sumaira BJK, Amjad TS. Determinants of profitability panel data evidence form insurance sector of Pakistan. Elixir International Journal. 2013;57A:14377-14382.

18. Ahmadimousaabad A, Anuar MA, Sofian S, Jahanzeb A. Capital Structure Decisions and Determinants: An Empirical Study in Iran. International Research Journal of Applied and Basic Sciences. 2013;5:891-896.

19. Chang VY. Determinants of the demand for reinsurance for U.S. property-liability insurance industry: Quantile regression analysis. Management Review. 2014;34:125-138.

20. Ammari S, Kadria M, Ellouze A. Board structure and firm performance: evidence from French firm listed in SBF 120. International Journal of Economics and Financial Issues. 2014;4:580-590.

21. Elango B, Luenma Y, Pope N. An investigation into the diversificationperformance relationship in the U.S. property-liability insurance industry. J Risk Insur. 2008;75:567-591.

22. Hardwick P, Adams M. Firm size and growth in the United Kingdom. School of finance and law, working paper. Insurance market, Applied Finance, Economic. 13, 133-143. Insurance. 1999;71:469-499. 